\title{
Formal capacities and relational understandings: Greed in literature, art and sociology
}

\section{Wendy Griswold*}

\begin{abstract}
In considering the uses of literature for the sociologist, we recognize that literature, art, and sociology all depict relationships. Producers (authors, artists, sociologists) craft relationships into cultural objects (novels, paintings, monographs); thereupon, receivers (readers, viewers) draw or infer relationships from these objects; producers, objects, receivers mutually construct and reconstruct one another over time. Literature, art, and sociology have different formal properties, however, and these different capacities shape how the receivers infer relationships from them. This article takes the example of greed to analyze sociological, artistic, and literary objectifications and to illuminate how the three genres' distinctive formal properties influence their specific capacities to engender relational understanding. This analysis indicates why sociologists should view none of these genres as a subset of another.
\end{abstract}

Keywords: Literature, Art, Novel, Greed, Sociology of literature.

*Northwestern University. Illinois, United States 


\section{Capacidades formales y entendimientos relacionales: codicia en la literatura, el arte y la sociología}

\section{Resumen}

Al considerar los usos de la literatura para el sociólogo, reconocemos que la literatura, el arte y la sociología describen relaciones. Los productores (autores, artistas, sociólogos) se dedican a transformar relaciones en objetos culturales (novelas, pinturas, monografías); a su vez, los receptores (lectores, espectadores) extraen o infieren relaciones de estos objetos; productores, objetos, receptores se construyen y reconstruyen mutuamente a lo largo del tiempo. Sin embargo, la literatura, el arte y la sociología tienen diferentes propiedades formales y estas capacidades diferentes dan forma a cómo los receptores deducen relaciones a partir de ellas. Este artículo toma el ejemplo de la codicia para analizar objetivaciones sociológicas, artísticas y literarias y para aclarar cómo las propiedades formales distintivas de los tres géneros influyen en sus capacidades específicas para engendrar el entendimiento relacional. Este análisis evidencia por qué los sociólogos no deberían ver ninguno de estos géneros como un subconjunto de otro.

Palabras clave: literatura, arte, novela, codicia, sociología de la literatura.

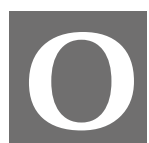

ur thinking begins with a consideration of primacy in three domains: Literature, art, and sociology. Sociologists of literature encounter questions like: Is literature a sub-class of art or entirely separate? How should sociologists think about this question? More generally, what is the relationship between sociology and literature? Given that the novel, by far the preeminent literary genre of the modern era, engages in social analysis as its primary object, where does literature stop, and sociology start? Is the distinction between the two simply another cultural boundary, historically rooted but ontologically arbitrary?

While we might dismiss resolving the question of who is the queen of the arts and sciences, merely posing it draws our attention to the distinctions among the three. We can easily see what they have in common: All three focus on relationships, relationships that may be social, spatial, temporal, 
metaphysical, and/or material. Not all areas of human thought do this meditation practices, for example, entail a radical ignoring of relational thinking - but the arts and sciences do, and the three in question are especially relational.

In the following, I would like to focus specifically on the formal dimensions of sociology, art, and literature in order to unpack their various capacities. I will illustrate this exploration by a consideration of greed. Using this example, I will argue that literature's formal capacities differ from those of art and sociology, and that therefore it is not a subset of either. Instead, its formal qualities give it the capacity to portray the interactions of the social and the individual over time, and it is from this representation of temporality that sociologists may draw benefit.

\section{In the beginning: greed in western theology}

Greed or avarice is an inordinate desire that excludes other values. We may view it as individual or as relational, either as a personal vice or as vicious only in relationship to other people. As an individual attribute, greed, one of the seven deadly sins, is a deformation of the soul. Thus, Augustine of Hippo distinguished between being rich and being avaricious; being wealthy was not a sin per se (although the rich should give of their resources to help others), while greed was. In The City of God Augustine wrote:

Greed is not a defect in the gold that is desired but in the man who loves it perversely by falling from justice which he ought to esteem as incomparably superior to gold; nor is lust a defect in bodies which are beautiful and pleasing: it is a sin in the soul of the one who loves corporal pleasures perversely, that is, by abandoning that temperance which joins us in spiritual and unblemishable union with realities far more beautiful and pleasing; nor is boastfulness a blemish in words of praise: it is a failing in the soul of one who is so perversely in love with other peoples' applause that he despises the voice of his own conscience; nor is pride a vice in the one who delegates power, still less a flaw in the power itself: 
it is a passion in the soul of the one who loves his own power so perversely as to condemn the authority of one who is still more powerful. (Augustine, 2008, p. 259)

Thus, greed was an individual failing, a radical case of mistaken priorities. Augustine does not focus on its impact on other people but on its impact on the soul of the avaricious.

Commentators have debated over the Christian position on wealth per se: Are the souls of the rich always in jeopardy (which seems to be the "eye of the camel" implication), or is the sin greed and not wealth (which seems to be the implication of Biblical accounts of wealthy people who are nonetheless devout)? While there were differences of opinion even among the Church Fathers (Ambrose seems to have taken a dimmer view of the rich than Augustine did), the general consensus is that the early Church regarded both poverty and wealth as morally neutral conditions. The rich run the greater risk of allowing their economic lives to absorb their attention (i.e., they are more likely to fall into greed, which is the actual sin), however, and moreover they have a particular obligation to assist the poor (See Pierson, 2013, Ch. 3 for a summary). Thus, greed was an individual sin of radically misplaced priorities, and it was unconnected with either degree of wealth or with the Christian ethics of human relationships that mandated charity toward the poor. ${ }^{1}$

\section{Greed in sociology}

Sociologists think in relational terms, of course. Typically, they are less interested in what moves people to behave the way they do, let alone in sin, and more interested in how human behaviors have consequences

${ }^{1}$ As Pierson sums it up, "For most of the Church Fathers, it was not what one possessed (or did not possess) but one's attitude to those possessions that counted. Riches were, properly, a matter of some indifference. It was avarice not wealth that was the vice and it was just as possible for a poor man as for a rich one to be avaricious. Nonetheless there was a requirement ot share one's wealth, particularly with the poor and needy..." (Pierson, 2013, p. 75). 
whereby one group's actions affect another. ${ }^{2}$ Thus sociologists typically avoid motivational analysis in favor of structural, particularly in empirical, synchronic analysis of quantitative data. ${ }^{3}$ Outcomes, not attitudes, are what matter. Even research that focuses on how people think about, for example, "the rich" does not specifically inquire about their imputed motivations, this despite the fact that the popular culture assumes that "the one percent" are greedier than everyone else. ${ }^{4}$

In the background of contemporary social science stand two positions on greed, conventionally associated with Thomas Hobbes on the one hand, Jean-Jacques on the other. The goal is social order and the question is, does greed knit together the social order or chip away at it? Hobbes saw men as naturally greedy, acquisitive, ready to kill others in the pursuit of wants, and only a strong sovereign power was needed to regulate this aspect of human nature and prevent a war of all against all. Rousseau saw people as naturally peaceful and only when they came together in society did envy and competition arise; greed was not innate but a social byproduct and could be held in check if people mutually participated in a social contract. Later social theorists up to the present day have presented variations on these positions. Adam Smith, for example, agreed with Hobbes about human nature but drew the opposite conclusion about the state; he saw human acquisitiveness and competition as good, as holding society together

${ }^{2}$ But see Lyman's (1978) collection of essays relating the traditional seven deadly sins to sociological questions.

${ }^{3}$ A reviewer has usefully pointed out that survey analysis and quantitative sociology referenced here may be more dominant in Anglo-Saxon sociology than in Brazil and elsewhere. I would add that while much comparative-historical analysis privileges structural analysis as well, such work tends to be more theory driven and shares common ground with the humanistic disciplines.

${ }^{4}$ For an apparent exception, see http://thesocietypages.org/eye/tag/greed/. However, this blog by emeritus sociology professor Ron Anderson actually supports the case, for Anderson admits that Obama never actually said that Wall Street people were greedier, and while he refers to his earlier review of a pop-sociology book about the rich, that review never mentioned greed either. This is typical: Unlike media commentators who are happy to talk about greed, progressive sociologists may imply it but generally avoid the language of virtues and vices. 
and benefiting everyone, as long as the state didn't get in the way. To take Sociology's Church Fathers, both Marx and Weber historicized the issue. Marx had little interest in individual motivations but in class relationships, and while Weber was more of a social psychologist than Marx, he saw the desire for even-increasing profit to be the defining characteristic of Western capitalism. Jumping ahead to the present, Robert Putnam (2015) famously charts and worries about the fraying of the social contract. For all such essentially secular social theorists, the issue isn't virtue or vice but the impact of specific behaviors on the society at large, and this is the standpoint of sociology as a discipline.

In a recent monograph, Leslie McCall, who has painstakingly dissected public attitudes toward the rich, finds that Americans see the "undeserving rich" as those people whose wealth works to limit opportunities for others, while the public tolerates the rich whose activities provide pathways for social mobility. As she sums it up, "Americans neither uniformly resent nor idolize the rich but, as a matter of equity, ask only that they fulfill their obligations to the American people, creating opportunity for all and not just for themselves" (McCall, 2013, p. 89-90). Whether or not the rich got to be rich because they were greedier than others (or harder working, or luckier) is beside the point for her analysis and seems to be beside the point for the American people as well. What matters is the relationship between the rich - their practices, their legal position, their money management, their taxation - and the rest of society.

Contemporary sociologists don't care where greed comes from, how universal it is, or what its implications are for salvation. What they/we care about are its effects when it is overtly manifest in behavior (the person who is greedy in her own heart but doesn't act on this greed is of no particular interest outside of theology). These effects, however, can be individual or social, and they can be stable or evolving over time. Here is where thinking about the capacities of art and literature comes in. 


\section{Greed in art}

First, we must acknowledge that neither art nor literature offer evidence, data in the scientific sense, about society. This is the generally held view: You cannot "read" a society from its arts or letters. A sociologist might analyze artistic or literary data to learn something about the production or reception of the cultural works or genres in question, but she will seldom rely on the cultural works as data to say something about society itself. What art and literature can do most powerfully for the sociologist is suggest hypotheses and pose them in the most vivid ways, including hypotheses about virtues and vices, individual attributes and social relationships. This is what is meant by the "expanding the horizons" arguments made to justify humanistic studies in schools, for example.

If we compare the formal properties of sociology, art, and literature, we might begin from their common ground. All three involve analysis of how the world is and how it works. Moreover, all three engage in the analysis of human relationships; sociology does so all the time, literature in the form of the novel does so most of the time, and art does so some of the time. They also share, but incompletely, some formal qualities. Both art and literature share the freedoms of play in Huizinga's sense (Huizinga 1955; Caillois 1979), while sociologically is rooted in the empirical, the real stuff of life, i.e., non-play. Both sociology and literature express their analysis in written texts, while art (as we are conceiving of it here) expresses its analysis in visual forms.

So, art is analytical, free (though characterized by conventions), and visual. As such, it expresses itself all at once, in a moment of viewing. This is not to say that a painting does not repay time invested in pondering it but only that its analysis is on immediate display. Its argument, so to speak, does not unfold over time, as with written texts, but is put forth at once. ${ }^{5}$

\footnotetext{
${ }^{5}$ Both my argument and my example apply to representational art of the Western tradition. Contemporary art has different properties and is more likely to unfold over time, for example where artists use video or other electronic media.
} 
A straightforward example of an artist putting forward greed comes in Quentin Metsys's painting of The Moneylender and His Wife, an allegory of avarice. In the late $15^{\text {th }}$ century Metsys settled in Antwerp, at that time a major trading center filled with moneylenders, currency exchanges, and other banking functions of early modernity. His painting is a commentary on greed as distraction, a shifting attention from the spiritual to the material.

Figure 1. Quentin Metsys, "The Moneylender and His Wife" (1514)

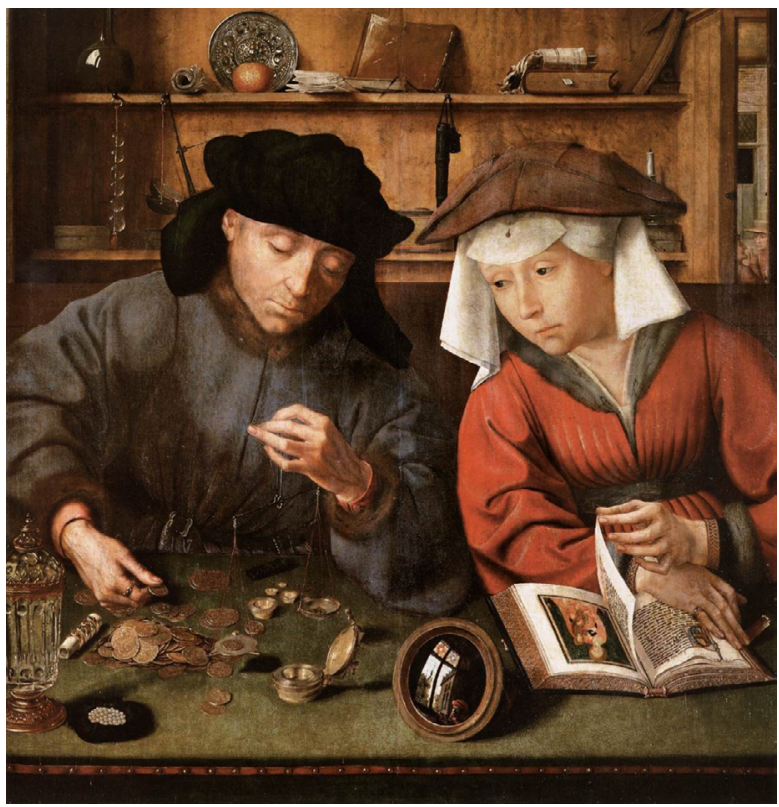

Source: https://www.louvre.fr/oeuvre-notices/le-preteur-et-sa-femme

The moneylender himself is doing what he does: counting pearls, weighing gold, sorting coins. He himself is not drawn away from his business; greed, and more specifically the conversion of money into money, is his 
business. It is his wife who is distracted from her devotional reading by the sight of so much wealth. The symbolism is heavy-handed here: the scales of judgment, the apple of temptation, the candle, the beads, and the mirror showing both the observing artist and the urban world outside the window where such dealings take place. All of these contrasts can be juxtaposed in the two-dimensional surface of the painting. There is no time, only a moment, domestic and dramatic, where the wife gives in to the lure of her greed.

Because of its visual immediacy, art is especially good at depicting contrasts: the saved and the damned, virtue vs. vice, and in this particular case, piety vs. greed. We see the temptation, the distraction, greed drawing the wife from some other value, in this case her devotions. The moment is sharply relational: The woman's relation to her husband, to her religion, and to her attraction to gold and jewels (the Louvre catalog description of the painting says that pearls were traditional symbolic of lust, another deadly sin and the erotic counterpart to greed). ${ }^{6}$ But it is just a moment.

\section{Greed in literature}

Paintings tend toward the synchronic, novels toward the diachronic. While the viewer doesn't take in The Moneylender and His Wife with a single glance, the typical pre-modern painting offers an image of a slice of time. ${ }^{7}$ Novels, again typically, move through time and, again before modernism, the time was typically linear. This formal difference allows the novel (and to a lesser extent other literary genres) to depict a multi-dimensional relational complexity as it plays out over time.

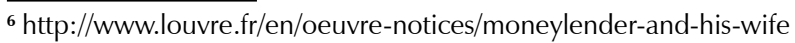

${ }^{7}$ Admittedly this is a gross generalization. Even aside from the temporal innovations of modernism, Renaissance paintings for example would sometimes do things like show several episodes from a saint's life in a single unified landscape.
} 
In the moment of the painting, greed has won, and such a moment is to some extent in accordance with the battle-for-the-soul idea of traditional Christianity. But not entirely, for things change and redemption is possible up until the moment of death. Paintings allow for multidimensional relationships. The moneylender and his wife are a married couple (social). They are next to each other, on the same plane, roughly the same height, and occupying roughly the same space (spatial). They are engaged with material objects: the scale, the book, the coins, and their dress (somewhat old fashioned, luxurious without being ostentatious). They have a relationship to the divine, though his is ignored and hers is wavering (metaphysical). So far, so good; we have a much richer picture of these two individuals than sociology would offer. But it is at a moment of time. We don't know if she will shake off temptation and return to her devotional reading. We don't know if he will see the candle and be reminded of the brevity of life and the threat to his soul. There is no story, only a pregnant moment when greed seems to be gaining the upper hand.

Here is where literature, and most specifically the novel, has the advantage. It is free play, like painting, but play over time. Relationships unfold, and we can observe complexity not just in terms of multiple factors but in terms of how multiple factors come into play over some period in people's lives.

Continuing with our greed example, lets look at Henry James's The Golden Bowl (1904), a late work that is considered his masterpiece. The story centers on four characters. Adam Verver is a fabulously rich American financier who comes to Europe to collect art for a museum he is building in American City. A widower for many years, he has an unusually close relationship with his daughter Maggie, who accompanies him on his journeys. Maggie is engaged to the Prince, an Italian from a noble Roman family that has lost its wealth. Finally, there is Charlotte, childhood friend 
of Maggie's, beautiful and moving in stylish social circles but herself poor and dependent on the generosity of her friends.

While the emotional intricacies that James puts forward are intricate, the plot itself is simple as it plays out over about six years. Book One is called The Prince, and it intermittently focuses on his point of view as well as that of an observer, Mrs. Assingham, who had brought the couple together originally. At the onset Charlotte comes to London shortly before Maggie and the Prince, somewhat stunned by his turn of fortune, are to marry. As Charlotte and the Prince shop for Maggie's wedding present and contemplate a beautiful but flawed golden bowl, it becomes apparent that, unbeknownst to the bride-to-be, they share a past as lovers, a past that the Prince wants to remain buried.

Three years pass. Maggie, now a mother, worries increasingly that her father is lonely without her undivided attention. In a conversation in the garden at Fawns, the country estate in Kent where Adam is hosting his daughter and son-in-law along with various visitors, Maggie urges him to marry and suggests Charlotte as a possible candidate. Charlotte arrives and, on a journey to Brighton, Adam duly proposes. They go to Paris to await Maggie and the Prince, who are in Rome, and upon receiving a telegram from the Prince, Charlotte, who has initially been hesitant, accepts Adam's proposal.

Two years pass. The two couples, both living in London, are together constantly. Maggie seems to devote more time and attention to her father than to her husband (let alone her son, who is adored by his grandfather), thereby often leaving the Prince and Charlotte, now his mother-in-law, in each other's company. Charlotte moves in a glamorous social milieu, bedecked with jewels but increasingly ignored by her husband and increasingly accompanied by the Prince. The latter continues to be cautious, not wanting to rock the boat and having some affection for his wife, while Charlotte, bored and passionate, is more reckless. The inevitable happens: Escaping to Gloucester after an erotically charged weekend at Matcham, the aptly 
named estate of a titled cougar intent on seducing a young guest, the Prince and Charlotte reignite their affair.

Book Two is from the point of view of The Princess. It draws in sharply, focusing almost exclusively on Maggie's shifting perceptions and turns of mind. It also draws in both geographically - the principals never leave London except for a few days at Fawns - and temporaly, for the Book takes place over the course of a few weeks. Some days after the Gloucester tryst, Maggie begins to sense that "something had happened," an awareness that becomes sharpened in the following weeks by her perception that Charlotte and the Prince were suddenly being hyper-attentive

that they were treating her, that they were proceeding with her - and, for that matter, with her father - by a plan that was the exact counterpart of her own [i.e., to carry on as if all were well]. It was not from her that they took their cue, but - and this was what in particular made her sit up - from each other... They had a view of her situation, and of the possible forms her own consciousness of it might take - a view determined by the change of attitude they had had, ever so subtly, to recognize in her on their return from Matcham.... [The had] a worked-out scheme for their not wounding her, for their behaving to here quite nobly... a bath of benevolence artfully prepared for her. (James, 1995, p. 256-57)

As Maggie's suspicions are increasingly confirmed (ultimately so when she purchases the golden bowl and the seller reveals the intimacies shared by the Prince and Charlotte years before), her main concern is that her father should never know about his wife's infidelity and, more importantly, about his daughter's pain. "'He did it for me, he did it for me', she moaned, 'he did it, exactly, that our freedom - meaning, beloved man, simply and solely mine - should be greater instead of less; he did it, divinely, to liberate me so far as possible from caring what became of him'" (James, 1995, p. 279).

So, Maggie swings into action. She lets her husband know she is on to him, without ever actually saying so. She confronts Charlotte, conveying her knowledge of "the unuttered and the unutterable" while cowing her into submission. In doing so, Maggie sets up a situation ("I accuse you 
of nothing") whereby Charlotte and the Prince will have to continue to pretend to their spouses as though nothing has happened, and no one knows otherwise.

And most significantly, she convinces her father that she has been selfish in keeping him from American City and his museum project. Thus, she arranges that her father and Charlotte will return to America while she and the Prince remain in London. "You're too splendid," remarks Mrs. Assingham, "You've done it... They're going... [Charlotte] sees it all before her - and she can't speak or resist or move a little finger...I see the long miles of ocean and the dreadful great country, State after State - which have never seemed to me so big or so terrible. I see them at last, day by day and step by step, at the far end - and I see them never coming back" (James, 1995, p. 407). Having successfully spared her father distress and having sent the rival for her husband's affections off to the "dreadful great country," Maggie has an "instant of terror" at the price she had paid, the loss of her father's daily companionship. The Prince is awed by her success ("I see nothing but you"), and, no longer the innocent child but the worldly woman, she allows herself to be buried in his arms.

Throughout his career James pursued his "International Theme," specifically the interaction between sophisticated Europeans and naïve Americans, and he set his novels in places where Americans and Europeans mixed. In The Golden Bowl three Americans and one Italian are the principals, with an Englishwoman and her husband occupying a secondary position. The setting is European: London, the Kentish countryside, Brighton, Gloucester, Paris, and Rome. The Americans are not exactly expatriates - they have come to Europe to collect (art, lovers, husbands) and two of the three will return to American City - but they are outsiders and the Europeans see them as appealing children. 
Two metaphors run throughout The Golden Bowl: predator/prey and money. Each of the principals is a predator, each is after something. The Prince has been after a wealthy wife, and at the opening of the novel, "Capture had crowned the pursuit" (James, 1995, p. 4). Adam Verver has been after European masterpieces for the museum he is building in American City. Charlotte is after a former lover and, almost secondarily, after a husband who can relieve her poverty. And Maggie is after a fiancé, later husband, whom she loves, yet at the same time she is after an unchanged intimacy with her father. Yet at the same time, each is prey, is threatened. The Prince is being seized, expropriated by the wealthy Americans; Maggie teases him that he is a part of [Adam's] collection... one of the things that can only be got over here. You're a rarity, and object of beauty, and object of price" (ibid., p. 8). Maggie sees her father as the innocent, defenseless, whom she must protect from the knowledge of his wife's adultery. Charlotte is the victim of her poverty, her earlier rejection by the Prince, and then her entrapment in a loveless marriage. And Maggie is the loving wife betrayed by the two heartless schemers. The country house where much of the action takes place is called Fawns, an apt image of helpless prey, and it is foreshadowing that in the first seen at Fawns, Adam the wealthy widower must thwart the designs of some encircling American women (the wonderfully named Mrs. Rance and her friends the Miss Lutches).

Running through all of this is money, both literal and metaphoric. Examples abound and this one is typical. Mrs. Assingham is speaking with the Prince at the Ambassador's reception and thinking

how it had taken his father-in-law's great fortune, and taken no small slice, to surround him with an element in which, all too fatally weighted as he had originally been, he could pecuniarily float; how strange it was that, with all allowance for their merit, it should befall some people to be so inordinately valued, quoted, as the said in the stock-market, so high, and how still stranger, perhaps, that there should be cases in 
which, for some reason, one didn't mind the so frequently marked absence in them of the purpose really to represent their price... he after all visibly had on his conscience some sort of return for services rendered. He was a huge expense assuredly - but it had been up to now her conviction that his idea was to behave beautifully enough to make the beauty well-nigh an equivalent. And that he had carried out his idea, carried it out by continuing to lead the life, to breathe the air, very nearly to think the thoughts, that best suited his wife and her father... (James, 1995, p.154)

The reigning symbol of the golden bowl combines this literal and metaphoric money. The gilt crystal bowl has a both a monetary price (fifteen pounds, the dealer tells Charlotte) and a symbolic value as wedding gift, as seal to the Prince's and Charlotte's renewed intimacy, and as ultimate confirmation of Maggie's suspicions. It also had a flaw (the same dealer, five years later, confesses to Maggie that the bowl was not worth the price she had paid). When Mrs. Assingham intentionally shatters it, its monetary value is destroyed, but not its metaphoric value attesting to the complex of the beautiful and the flawed, the symbol of a naïve image of perfection replaced by a worldly assessment of the costs of our actions.

In such a world, greed is no longer an individual vice (as in theology and art). It is both social and systemic. Indeed, the principals are not especially greedy. ${ }^{8}$ In marrying their spouses, Charlotte and the Prince are simply doing what they have to do to survive; their greed, if it be such, is not monetary but sexual, in thinking they can be each other's bit on the side without jeopardizing their marriages. Maggie and Adam both "collect" (art, princes) and they have the obliviousness that comes with wealth, but at the same time they are careful not to hurt anyone else and there is no sense that their

\footnotetext{
${ }^{8}$ The word "greed" appears only twice in the novel, and is disavowed in both cases. At the beginning the Prince has to "warn himself in short against arrogance and greed...Personally, he considered, ha hadn't the vices in question - and that was so much to the good. His race, on the other hand, had had them handsomely enough, and he was somehow full of his race" (James, 1995, p.11), so we see James's suggestion of greed being social rather than personal. Later Adam, while constantly having to fend off Mrs. Rance's advances, resists complaining, even to himself. "Complaint, besides, was a luxury, and he dreaded the imputation of greed" (ibid, p.76).
} 
collecting is a distraction from their care for human relationships. For all of the characters social greed comes in the form of the absolute necessity of money to sustain their way of life and in their relentless though unconscious evaluation of people and situations in monetary terms. Social greed can be seen as a distraction from other values - social harmony, personal relations free from the cash nexus - and in that sense it is specifically a vice of capitalism at large rather than of greedy individuals.

Moreover, each person's participation in what we are calling social greed evolves over time. Charlotte and the Prince are in webs of gender and status whereby they cannot survive socially if they don't marry wealth; this is why their love affair faltered in the first place. After their marriages, their self-protection and their vulnerability - prey to economic pressures and, in Charlotte's case, to conventional gender roles - is why they are so obsessed with discretion, with "treating" Maggie carefully. Social greed distracts them all along, first from their mutual erotic love, later from their spouses, and ultimately from their realization of their full selves and desires.

Adam Verver is a spinner of, as well as caught up in, geopolitical webs of industrial capitalism, imperialism, and the ravishing of cultural heritage - all while being in everyone's eyes a decent and essentially innocent man (Adam before the fall). The man of money has become the man of taste, the amassing of wealth makes possible the amassing of art, but James presents such manifestations of social greed as systemic rather than as a feature of Adam's personality. Adam's collection evolves: He has been collecting art treasures, he goes on to collect a beautiful wife, but he goes on to lose his dearest (in both senses) treasure, the daily communion with his daughter.

And Maggie of course is the character who evolves more dramatically. Initially she is acted upon, an object for an Italian fortune hunter, for Mrs. Assingham's meddling, and for Charlotte's condescension. Even as 
she steers her father toward marriage, she describes herself as "a small, creeping thing" in comparison with Charlotte. Her greed is her naïve assumption that she can have it all: her Prince, her father, her friend, and her obliviousness to the machinations of those around her. But in the economic and social ocean in which she swims, such omnivorousness is not possible, and this is what she must learn. Ultimately, she is the active character, moving the others so that she may preserve as many of her gains as possible. She keeps her marriage and, arguably, her father's ignorance, but at the cost of her loss of the one person she loves most as well as her initial innocence.

\section{In conclusion}

Modernity is the subject of sociology. The artistic and literary examples we have used to illustrate our discussion come from the early modern period, when commerce was reorganizing urban life, and from the turn of the twentieth-century, when industrial capitalism had exploded traditional social ties and sociology as a discipline was picking through the ruins (note that The Golden Bowl came out one year before Weber's The Protestant Ethic and the Spirit of Capitalism). But if sociology, art, and literature all can be examinations of the modern social world, they do so with varying capacities.

We see evolutions over the time-span of the novel, and this highlights what literature gives us that art cannot: a picture of how the social works on human beings over the course of their lives. Greed in our example is not a single distraction, a momentary fall from grace, nor is it a variable that can be indexed through a survey or observed in the field. Social greed is central to the "webs of significance," in Clifford Geertz's sense, that made up modernity. Geertz (1973) famously described culture in these terms: "Man is an animal suspended in webs 
of significance he himself has spun. I take culture to be those webs, and the analysis of it to be therefore not an experimental science in search of law but an interpretative one in search of meaning." The novelist, like the cultural sociologist, acts as the analyst, but the former has the great advantage of being able to present the webs of significance and how people move in them over time.

Form matters. It is a mistake to think of literature as some subset of art, or the novel, despite its focus on social analysis, as some subset of sociology. The three have different formal properties that allow for different investigations into and representations of different facets of human experience. For the sociologist literature does not offer answers but raises questions. It suggests hypotheses based on the temporal unspooling of human relationships over a complex social and cultural topography. We would not want to subsume its power of suggestion by conceiving of it as a category of something else.

Wendy Griswold is Professor of Sociology and Bergen Evans Professor in the Humanities at the Northwestern University, Illinois, USA.

Đw-griswold@northwestern.edu 


\section{References}

1. AUGUSTINE OF HIPPO (Saint Augustine). The City of God: Books VIII - XVI. Translated by Gerald G. Walsh, S.J. and Grace Monihan, O.S.U. Washington, D.C.: Catholic University of America Press, 2008.

2. CAILLOIS, Roger. Man, Play, and Games. New York: Schocken Books, [1961] 1979.

3. GEERTZ, Clifford. The Interpretation of Cultures. New York: Basic Books, 1973.

4. HUIZINGA, Johan. Homo Ludens: A Study of the Play Element in Culture. Beacon Press, Boston, [1938] 1955.

5. JAMES, Henry. The Golden Bowl. London: Wordsworth Editions Limited, [1904] 1995.

6. LYMAN, Stanford M. The Seven Deadly Sins: Society and Evil. New York: St. Martin's Press, 1978.

7. McCALL, Leslie. The Undeserving Rich: American Beliefs about Inequality, Opportunity, and Redistribution. Cambridge and New York: Cambridge University Press, 2013.

8. PIERSON, Christopher. Just Property: A History in the Latin West. Volume One: Wealth, Virtue, and the Law. Oxford: Oxford University Press, 2013.

9. PUTNAM, Robert. Our Kids: The American Dream in Crisis. New York: Simon \& Schuster, 2015. 